\title{
ORDER OF ADJECTIVES AND ADVERBS IN L2 ENGLISH: EVIDENCE FROM L1 ACHOLI SPEAKERS OF UGANDAN ENGLISH
}

\author{
Sarah Amarorwot ${ }^{1}$, Bebwa Isingoma ${ }^{2}$ \\ ${ }_{1,2}$ Department of Languages and Literature (English language and Linguistics section) \\ at Gulu University (Uganda)
}

\begin{abstract}
L2 Englishes are quintessentially characterized by cross-linguistic influence at all levels of linguistic analysis as a result of contact phenomena. This study examines the contribution of the syntax of a Ugandan indigenous language (Acholi) to how its L1 speakers speak English and the extent of variability observed among them, taking into account two grammatical aspects, i.e. how multiple attributive adjectives are sequenced in a noun phrase and the placement of adverbs in a sentence. The findings of the study show notable differences from L1 English (e.g. Standard British English), as L1 Acholi speakers of English do not necessarily pay attention to the prescribed L1 English order of adjectives. At the same time, the position of adverbs in a sentence also seems to be modeled, to some extent, on what takes place in Acholi syntax insofar as some legitimate L1 English structures are rejected by L1 Acholi speakers of English (as L2). Crucially, the study also reveals interspeaker variability among L1 Acholi speakers of English in Uganda based on occupation, with students being the closest to L1 English norms (as opposed to teachers and the business community), most likely due to exonormative orientation imposed on students in Ugandan schools.
\end{abstract}

Key words: Acholi, Ugandan English, adjectives, adverbs, variability

About the author: Sarah Amarorwot is a graduate trainee at the Department of Languages and Literature (English Language and Linguistics Section) at Gulu University (Uganda). She is a trained teacher of English and Literature in English. Her research interests are in the fields of sociolinguistics and syntax. She participated in the collection, compilation and transcription of data for the International Corpus of English - Uganda (2018-2020).

e-mail: amarosarah629@gmail.com

ORCID iD: https://orcid.org/0000-0001-8642-7555

About the author: Bebwa Isingoma earned his PhD in English Linguistics in 2013 at the University of Agder (Norway) after completing his MPhil at the Norwegian University of Science and Technology. He is an EU Marie S. Curie fellow (Freiburg Institute for Advanced Studies, Germany, 2018/19) and a fellow of the African Humanities Program (Rhodes University, South Africa, 2015). His research interests include (variational) sociolinguistics, English syntax, cognitive pragmatics and Bantu linguistics. He is currently a Senior Lecturer in English Language \& Linguistics and Dean of the Faculty of Education \& Humanities at Gulu University (Uganda).

e-mail: b.isingoma@gu.ac.ug

ORCID iD: https://orcid.org/0000-0002-1203-5951

isibebwa@yahoo.co.uk

Copyright $(92021$ Sarah Amarorwot, Bebwa Isingoma

Article history: Received: 26 August 2021; Reviewed: 31 October 2021; Revised: 4 November 2021; Accepted: 4 November 2021; Published: November 2021

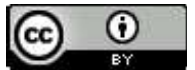

This open access article is published and distributed under a Creative Commons Attribution 4.0 International License.

Citation (APA): Amarorwot, S., \& Isingoma, B. (2021). Order of adjectives and adverbs in L2 English: Evidence from L1 Acholi speakers of Ugandan English. Studies in Linguistics, Culture, and FLT, 9(3), 4462. https://doi.org/10.46687/YXUV9786. 


\section{Introduction}

English in Uganda is a co-official language together with Swahili. However, functionally, English is the only official language, with Swahili only relegated to the army. It is the language of the judiciary, parliament, international business and educational institutions (Isingoma \& Meierkord, 2019). Ugandans mainly acquire English at school and proficiency depends on many factors, one of which is higher educational attainment. Just like other Ugandans, native speakers of Acholi who have attained higher educational echelons are typically proficient acrolectal speakers of English. Acholi is one of the main languages in Uganda and it belongs to the Western Nilotic clade (Eberhard, Simons \& Fennig, 2021).

As will be seen in Section 2 below, a sequence of attributive adjectives in English and the occurrence of adverbs in a sentence occupy specific slots licensed by the syntax of the language. On the other hand, the syntax of Acholi (see Section 5) with respect to the order of adjectives and adverbs does not behave in the same way as the syntax of English. It is therefore expected that the asymmetries between the two grammars may have a bearing on how speakers of Acholi use these grammatical aspects in English as a L2. It has been argued by e.g. Ssempuuma, Isingoma and Meierkord (2016) that each Ugandan language exerts its influence on how L1 speakers of the language speak English, although sometimes certain grammatical aspects may be similar in different substrate languages, while other second language learning processes such as generalization and leveling may also have an influence on how Ugandans speak English generally. The present study looks at two grammatical aspects, namely the order of adjectives and the order of adverbs in English, as used by speakers of English whose mother tongue is Acholi. It primarily seeks to establish how a Ugandan language may be at the heart of the divergences between L1 English and L2 English (even though it recognizes the role of other forces in second language acquisition). Crucially, the study also seeks to establish whether belonging to a given speaker group in terms of occupation also has a bearing on how one uses the grammatical aspects under consideration in this study.

\section{Order of adjectives and adverbs in L1 English}

In English, adjectives occur either attributively (e.g. I bought a comfortable chair) or predicatively (The chair I bought is comfortable). As can be seen, the adjective comfortable can occur both attributively or predicatively, unlike the adjective glad, which occurs predicatively only, or sole, which occurs attributively only (cf. Hasselgård, Lysvåg \& Johansson, 2012). When there are multiple adjectives occurring attributively in an English noun phrase, there is a specific ordering system, as presented by Carter and McCarthy (2006, p. 450) in the following (1), with a possible example in (2): 
(1)

$\begin{array}{ll}\begin{array}{l}\text { evaluation } \\ \text { physical }\end{array} & \text { (e.g. wonderful) } \\ \text { quality } & \text { (e.g. monumental) } \\ \text { shape } & \text { (e.g. strong) } \\ \text { age } & \text { (e.g. old) } \\ \text { color } & \text { (e.g. black) } \\ \text { participle } & \text { (e.g. written, smiling) } \\ \text { origin } & \text { (e.g. Indian) } \\ \text { material } & \text { (e.g. wooden) } \\ \text { type } & \text { (e.g. modern) } \\ \text { purpose } & \text { (e.g. log-carrying) } \\ \text { head noun } & \text { (e.g. elephant) }\end{array}$

(2) These wonderful, monumental, strong, old, grey, Indian, logcarrying elephants.

On the other hand, Hasselgård et al. (2012, pp. 228-229) give the following order (3):

$$
\begin{array}{ll}
\begin{array}{l}
\text { limiters } \\
\text { emphasizing adjectives } \\
\text { qualitative adjectives }
\end{array} & \begin{array}{l}
\text { (e.g. certain, same) } \\
\text { (e.g. evaluative }
\end{array} \\
\begin{array}{l}
\text { (b) descriptive } \\
\text { color adjectives and participles } \\
\text { origin, style, material } \\
\text { classifying adjectives }
\end{array} & \begin{array}{l}
\text { (e.g. heautiful, horrible) } \\
\text { (e.g. red, stolen) }
\end{array} \\
\text { (Irish, modern, woolen) }
\end{array}
$$
(a) evaluative
(e.g. beautiful, horrible)

(a) adjectives derived from nouns

(e.g. literary, medical,

social)

(b) uninflected nouns

(e.g. phone number, road sign)

While Hasselgård et al. (2012, pp. 228-229) include limiters, emphasizing adjectives and classifying adjectives, Carter and McCarthy (2006, p. 450) do not have them. For a native speaker, the above categories may be more or less obvious, but for a non-native speaker, it might be difficult to grasp such a sequence and the fact that there is already a native language that exerts its influence, one may logically expect some level of deviation.

A number of scholars, e.g. Kroeger (2004) and Zhang (2010), observe that the syntax of L1 English adverbs is fairly complex. This is because the position of, 
for example, adverbs which describe the speaker's evaluation of a proposition and adverbs of manner can be influenced by a wide variety of semantic and pragmatic factors, usually, with a number of exceptions, which makes the syntax of L1 English even more complex. Take, for example, the following sentences (4) and (5) slightly adapted from Kroeger (2004: 37):

(a) Probably Sarah will disagree with your theory.

(b) Sarah probably will disagree with your theory.

(c) Sarah will probably disagree with your theory.

(d) *Sarah will disagree probably with your theory.

(e) Sarah will disagree with your theory probably.

(5) (a) *Violently Sarah will disagree with your theory.

(b) *Sarah violently will disagree with your theory.

(c) Sarah will violently disagree with your theory.

(d) Sarah will disagree violently with your theory.

(e) Sarah will disagree with your theory violently.

The distribution of the two adverbs appears to be complex. The adverb probably does not occur inside the VP, while violently occurs inside the VP. This means that probably must be an immediate daughter of the $\mathrm{S}$ node, while violently must be an immediate daughter of the VP node (Kroeger, 2004). This is usually confirmed by the pause in (4e) before the adverb (usually represented by a comma in writing), while in (5), there is no pause (Kroeger, 2004).

Other examples of intricacies involve the following examples, where (6a) and (7a) are considered correct in L1 English, while (6b) and (7b) are incorrect:

a. Obviously, he had spoken loudly.

b. $\quad$ *Loudly, he had spoken obviously.

a. He luckily has wisely refused the offer.

b. $\quad *$ He wisely has luckily refused the offer.

In (6b), a manner adverb is used at the initial position of a sentence. Haumann (2007, p. 147) indicates that adverbs of manner such as loudly, unfairly, dimly are barred from initial positions, because they are not subject-oriented, as opposed to adverbs of manner such as calmly, clumsily and carefully, which, despite being adverbs of manner, are allowable sentence-initially (although Haumann (2007), thus, regards them as not being adverbs of manner proper). On the other hand, in (7b), a subject-oriented adverb cannot precede an evaluative adverb. Such subtleties may not be clear to non-native speakers of English (Zhang, 2010). 


\section{Order of adjectives and adverbs in L2 English}

Several studies (e.g. Kitikanan \& Dandmrongak, 2018; Harakawa, Shibuya \& Endo, 2019) have shown that although L2 English speakers hardly fully grasp how adjectives are ordered in English, the more language experience a L2 speaker has, the closer to native-like proficiency in adjective ordering they will have. The studies above involved Thai and Japanese L2 English speakers, respectively. The reason for the difficulties encountered by these L2 English speakers is the fact that their L1s do not have such an intricate order of adjectives. Similar results have been reported by Wulff \& Gries (2015) in relation to Chinese and German L2 speakers of English, also highlighting the role of L1 in the variability observed.

According to McMahon (2008), many speakers of Asian Englishes (i.e. L2 Englishes) such as Japanese, Chinese and Koreans would find no error in saying a yellow dirty dog, while a native speaker of English would naturally correct that to a dirty yellow dog. This is because in L1 English, the order of attributive adjectives requires color adjectives to come after qualitative adjectives (cf. Hasselgård et al., 2012).

A study conducted by Karpava (2017) among Russian and Greek Cypriot L2 speakers of English, aiming at finding out "whether structural differences and similarities among English, Russian and Greek lead to facilitative or negative syntactic transfer effect in L2 acquisition of English", reveals that "there is a facilitative transfer from L1 Russian into L2 English and negative transfer from L1 CG [Cypriot Greek] into L2 English [our square brackets]" (Karpava, 2017, p. 49). This is due to structural similarities observable between Russian and English, on the one hand, and structural differences between Greek and English, on the other, in relation to adverb placement.

According to Schmied (2004, p. 936), "the strict English word order rules for adverb positions are weakened" in East African English (Kenya, Uganda, Tanzania). He states that "some adverbs tend to come as an afterthought, often without a break at the end of the clause or sentence, as for example unfortunately", while "others can be found at the very beginning", for example the temporal adverb already. However, it is not clear whether this should be regarded as a typical feature of L2 English, as Cambridge Dictionary Grammar shows, for example, that already can be topicalized/fronted but only in formal settings (e.g. Already, I have made coffee).

\section{Data and Methodology}

Our study consisted of 60 participants who took part in semi-structured interviews and an elicitation test. The semi-structured interviews enabled us to record 14,000 words eliciting some uses of adverbs and multiple adjectives 
in sentences. All the participants were acrolectal speakers of English, having completed at least 13 years of English education in line with the ICE data compilation requirements (Greenbaum \& Nelson, 1996). We modelled the categories of participants in terms of occupation on the criteria used for the collection of ICE-Uganda data, namely students, professionals (teachers of English in our case) and the business community. The semi-structured interviews were transcribed and saved as text files. Then, the data was searched using the corpus concordance analyzer software AntConc (cf. Anthony, 2014). The text files were then sorted and analyzed manually. The items searched were adverbs and multiple adjectives.

Due to the size of our corpus and the nature of the elicited grammatical aspects, we supplemented our data with an elicitation test in order to capture, for example, instances of multiple occurrences of adverbs (which were conspicuously absent in our small corpus data) as well as more instances of multiple adjectives. The 60 participants who took part in the semi-structured interviews were also employed in the elicitation test. The test had 10 multiple choice questions in total, i.e. 7 items for adverbs and 3 items of adjectives (see Appendix II). The test was written in nature and was administered in a face-to-face environment, with respondents writing their answers on paper. It was supervised so that there were no consultations. It was open-ended in terms of duration. Participants were assigned 1 score for each correct answer.

\section{Results and Discussion}

\section{Order of adjectives}

Adjectives characterize entities by ascribing properties to them. In order to elicit the use of multiple attributive adjectives, the respondents were asked to describe their future partners in terms of physical appearance during the semi-structured interviews. The following adjectives were obtained from the data (8):

(8) a. I want to marry a tall, dark, handsome man.

b. A beautiful, slender, medium-size lady would do for me.

c. He should be nice looking of course, taller than me, dark complexion.

d. Medium-size, brown, portable.

e. I would want a brown, tiny, good-looking and presentable lady.

f. God-fearing is number one, caring and presentable.

$\mathrm{g}$. The man should be loving and caring, and of course tall.

The table below summarizes the attestation of multiple adjectives in the data and their normalized frequency. 
Table 1.

Attestation of adjectives

\begin{tabular}{|l|l|}
\hline Grammatical aspect & $\begin{array}{l}\text { Attestation (Normalized Frequency } \\
\text { per 1 million words) }\end{array}$ \\
\hline Order of adjectives & $7(500)$ \\
\hline
\end{tabular}

The above table shows that there were 7 strings of adjectives out of 14,000 words and the frequency would be 500 adjectives per one million words. As can be seen, for example, in sentences (8a) and (8e), the order of multiple adjectives used attributively does not respect the normative order that L1 English grammar books provide. Specifically, in (8a), an adjective belonging to the category of evaluation (handsome) comes after a descriptive adjective characterizing a physical quality (tall) as well as color (dark). This flouts the rule that requires the sequence where evaluative adjectives have to precede descriptive adjectives and both of these should precede color adjectives (Carter \& McCarthy, 2006; Hasselgård et al., 2012). Similarly, in (8e), the order presented here is color, description, participial adjective and evaluation. This is not what normative rules require. Instead, the order should be evaluation, description, color and participial adjective (Carter\& McCarthy, 2006; Hasselgård et al., 2012). Hence, normatively, the two sentences should look like this (9):

(9) a. I want to marry a handsome, tall, dark man.

b. I would want a presentable, tiny, brown, good-looking lady.

It should be noted that $(8 \mathrm{c})$ and $(8 \mathrm{~g})$ are cases of predicative adjectives; hence, the order does not matter, while in (8b), the adjectives are presented in a sequence that is acceptable in L1 English, i.e. evaluation (beautiful), size (slender) and nominal modifier (medium-size). On the other hand, (8d) and (8f) are fragments and it is therefore hard to tell whether the adjectives were used attributively or predicatively.

The elicitation test also sought to find out the respondents' familiarity with the order of adjectives. The graph below shows the total score of the respondents in relation to the use of adjectives: 


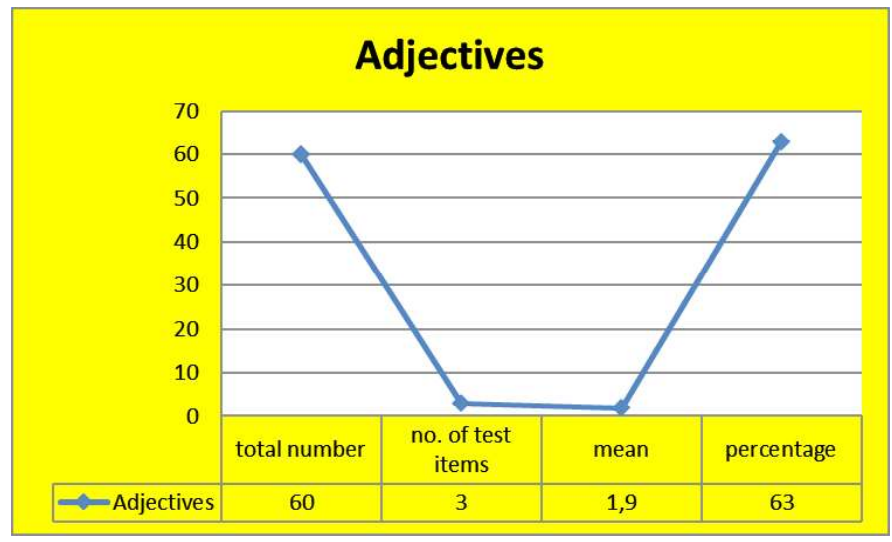

Figure 1. Order of adjectives in the elicitation exercise

The results show that the sixty respondents got an average score of $1.9(63 \%)$ out of the 3 test items. This means that up to $37 \%$ of the responses were not normatively correct in light of L1 English usage. This is interesting and can be said to reflect how Acholi L1 speakers of English (as L2) deviate from the norms, despite the emphasis that is placed on these norms in grammar books and teaching in secondary schools.

Substrate influence could be responsible for this, as in Acholi, adjectives are only used predicatively (cf. Kitching, 1932), with the equivalents of English attributive adjectives realized by means of a relative clause, which also requires a predicative use, as shown in $(10)^{1}$ :

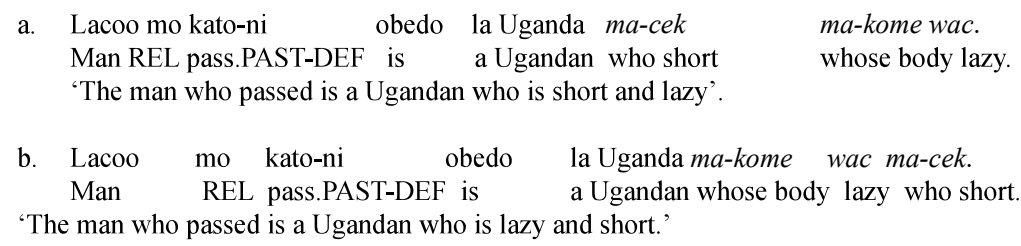

As can be observed, the equivalents of the adjectives short and lazy are used in a copula-less relative clause with no definite order, i.e. the two renditions in (10a) and (10b) are both acceptable. As is now evident, English has a specific adjective ordering system which varies from most languages which have no specifically correct or incorrect adjective ordering (McMahon, 2008). Predicative use of adjectives, as is the case in the Acholi examples above, does not require any specific order, even in English; e.g. I need to marry a man who is tall, black and handsome is acceptable in L1 English.

1. Abbreviations: $3 \mathrm{SG}=3^{\text {rd }}$ person singular, $\mathrm{DEF}=$ Definiteness, PRES $=$ Present tense, $\mathrm{PROG}=$ progressive aspect, $\mathrm{REL}=$ Relativizer 


\section{Order of adverbs}

From the corpus, we gathered a few adverbs as shown in (11):
a. I can wait patiently and quietly.
b. They responded slowly to the people.
c. They already wanted to try the drugs on us.
d. Uganda as usual will accept stupidly.
e. We wait for what will happen tomorrow confidently.

As can be observed, there were few occurrences of adverbs (11) and they are used in a similar manner as L1 English speakers use them. All of them are adverbs of manner save for (11c), which is a temporal adverb. Adverbs of manner are typically VP elements, while the temporal adverb already is usually placed before the main verb and when it is placed at the end of a sentence, it is used for greater emphasis (Cambridge Dictionary).

However, in the elicitation test, it was revealed that the respondents had deviations from the norms, as the figure below shows. The graph shows the total score of the respondents in relation to the use of adverbs.

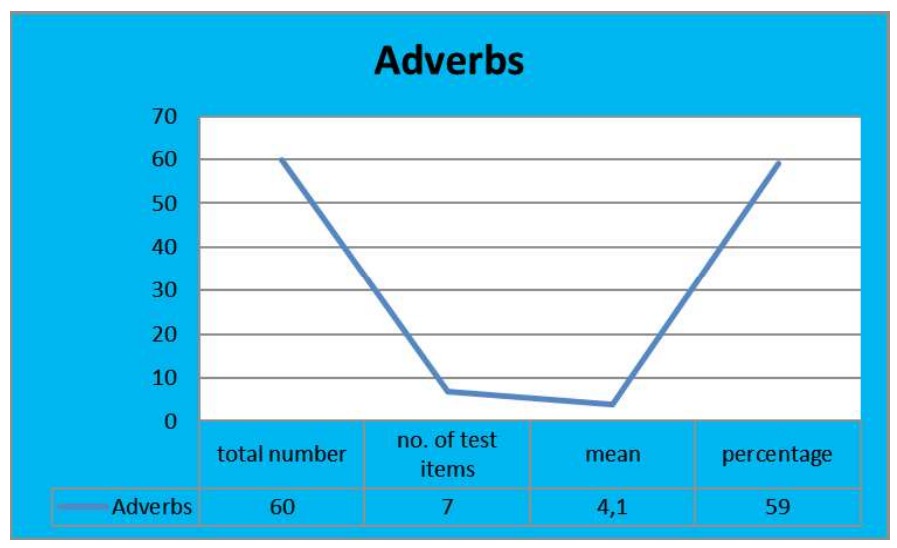

Figure 2. Total score for the use of adverbs

The results indicate that the sixty respondents got an average score of $4.1(59 \%)$ out of the 7 test items under the order of adverbs. Deviations were observed, for example, in Question 5 (repeated here as (12)) and Question 7 (repeated here as (13)):

(12) a. The man quickly removed his phone from the table.

b. The man removed his phone quickly from the table.

c. The man removed his phone from the table quickly.

(13) a. Clearly, Dorica probably will quickly learn French perfectly.

b. Probably, Dorica clearly will quickly learn French perfectly. 
Question 5, as shown in (12) above, consisted of three options which are all correct in Standard British English (L1 English) but all the participants rendered at least one option incorrect. The question intended to find out whether the respondents were familiar with the flexibility in the position of adverbs of manner in English. Despite being VP elements, adverbs of manner can be placed before the verb (as in (12a)) for emphasis purposes (BBC-Learning English).

For Question 7, as shown in (13), (a) is correct and (b) is incorrect but most of the participants rendered either both options correct or incorrect. Familiarity with multiple adverbs occurring in the same sentence was the main issue tested here. Adverbs (or specifically disjuncts) such as fortunately, hopefully, inevitably, understandably, which describe the speaker's evaluation of a proposition, and those that describe epistemic comments regarding truth probability (e.g. probably, possibly, apparently, clearly, seemingly, evidently, obviously) are elements of S (sentence), namely they modify a sentence as a whole; hence, they do not occur in the VP (Kroeger, 2004). ${ }^{2}$ However, when epistemic adverbs belong to the category of evidential modality (i.e. where the speaker is more certain, because there is evidence using adverbs such as clearly, evidently, obviously), such adverbs precede epistemic adverbs which encode less certain and less reliable epistemic modality (e.g. probably, possibly, apparently, seemingly) (Cinque, 1999, p. 33). Hence, (13b) is illicit because 'probably' precedes 'clearly'. As for the rest of the adverbs in (13) and as already pointed out above in relation to (12), the adverbs quickly and perfectly are adverbs of manner and are canonically elements of the VP, even though they may be placed before the verb for emphasis. What we observe from the answers provided by L1 Acholi speakers of English is that although, in the corpus data, they used non-multiple adverbs in the same way as native speakers of English use them, their familiarity with multiple adverbs occurring in the same sentence seems to be limited.

What also emerges from the above is that the L1 Acholi respondents might have invoked the rules governing Acholi to judge (12a) as being ungrammatical, since, in Acholi, an adverb of manner cannot be placed immediately before the verb, as shown in (14):

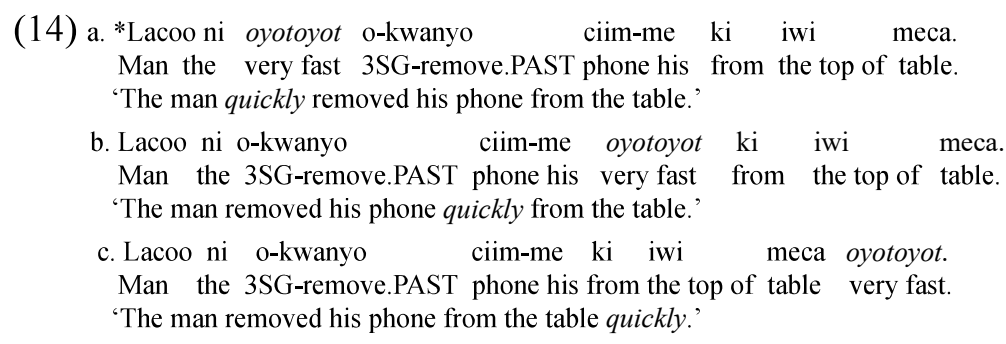

2. Note that in Kroeger's (2004) syntactic framework (i.e. Lexical Functional Grammar), auxiliaries are regarded as elements of S. 
As can be seen, the Acholi adverb of manner (oyotoyot 'quickly') is only allowed inside the VP as in (14b) and (14c). The pragmatically conditioned English language provision of allowing such adverbs to be placed immediately before the verb is not available for Acholi (14a). Hence, according to the UG framework (Chomsky, 1965, 1986, while adverbs of manner in both English and Acholi are primarily internal to the VP, that is, they are right-adjoined, English has a provision for leftadjoining due to pragmatic conditioning (i.e. for laying emphasis) - a property that Acholi lacks. Setting this parameter among the Acholi respondents may not have taken place, thereby letting them use the syntactic norms of their L1, i.e. translating into full lexical transfer (Sprouse, 2006).

Similar to the case in (14) is the use of the adverb of manner motmot 'slowly' in (15):

\begin{tabular}{|c|c|c|c|}
\hline $\begin{array}{r}\text { a. }{ }^{*} \text { Akello } \\
\text { Akello }\end{array}$ & $\begin{array}{l}\text { motmot } \\
\text { slowly }\end{array}$ & $\begin{array}{l}\text { tye } \\
\text { be.PRES }\end{array}$ & $\begin{array}{l}\text { ka-wot. } \\
\text { PROG-walk }\end{array}$ \\
\hline \multicolumn{4}{|c|}{ 'Akello is slowly walking.' } \\
\hline $\begin{array}{l}\text { b. Akello } \\
\text { Akello }\end{array}$ & $\begin{array}{l}\text { tye } \\
\text { be.PRES }\end{array}$ & $\begin{array}{l}\text { ka-wot } \\
\text { PROG-walk }\end{array}$ & $\begin{array}{l}\text { motmot. } \\
\text { slowly }\end{array}$ \\
\hline
\end{tabular}

As is the case in (14) above, while (15b) is acceptable, (15a) is not, due to an attempt to left-adjoin the adverb of manner motmot 'slowly'.

\section{Variability among speaker groups}

An analysis was conducted with respect to the order of adjectives as used by the different speaker groups (namely students, English teachers and the business community). The results obtained from the elicitation test can be visualized in the figure below:

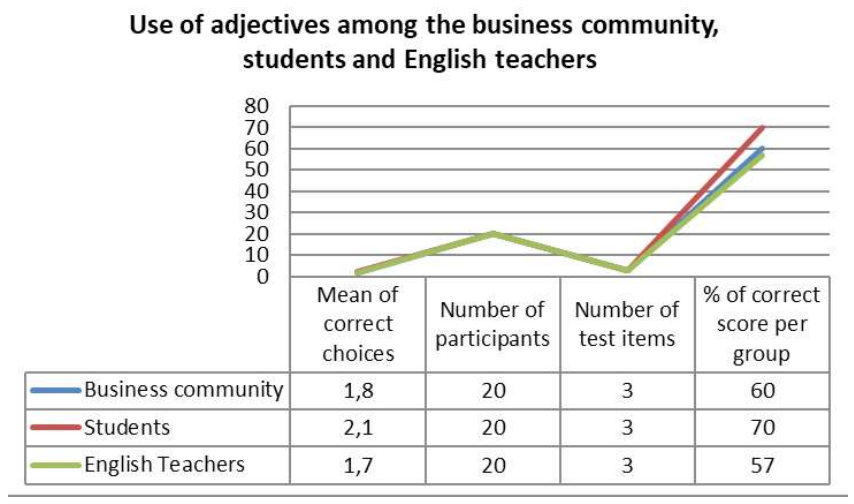

Figure 3. Correct answer rates for adjectives per speaker group

The results above show that out of the three test items of adjectives, the business community has an average score of $1.8(60 \%)$, while the students have 2.1 (70) 
and the English teachers have 1.7 (57). Based on these findings, the students have the highest score, while the teachers have the lowest score. This means that the teachers have the highest rate of deviations when using English adjectives. This was subjected to a significance test, which revealed a statistically significant difference in the mean scores of the different speaker groups when using English adjectives at 0.000 (see Appendix 1, Table 2).

To visualize the findings in relation to how adverbs were ordered among the three speaker groups, the following results were obtained from the elicitation test:

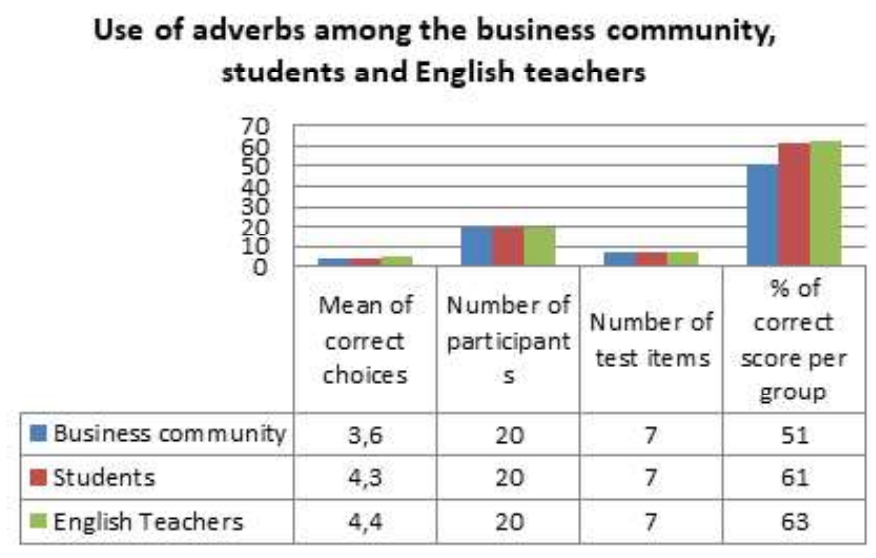

Figure 4. Correct answer rates for adverbs per speaker group

The study findings indicate that the average score of the students under adverbs was $4.3(61 \%), 4.4(63 \%)$ for the English teachers, and 3.6 (51\%) for the business community. The differences are statistically significant at 0.000 (see Appendix 1 , Table 3). The above findings therefore reveal that the business community has the lowest score as per the test items under adverbs. This, therefore, indicates that the business community has the highest rate of deviations when it comes to the use of English adverbs compared to any other category of the respondents.

The overall results from the elicitation exercise data show that the students had fewer deviations than the other two different categories of the respondents followed by the teachers and then the business community (see similar results in Meierkord \& Isingoma, 2021). This is quite interesting, because the English teachers are expected to have the grammatical rules at their fingertips since they are the custodians of knowledge. However, to some extent, the results are not surprising because, unlike students, teachers are free to use any other language apart from English as there are no strict rules that restrict them to the use of the English language. Since English is a second language to such English teachers, the fact that they do not use it all the time (save from when they are in class or when interacting with students on the school compound or in the staffroom), it might be the case that some of the grammar rules have evaporated (see also Meierkord \& Isingoma, 2021), which means that they will tend to 
deviate more from the exonormative norms, as these norms are maintained by a closer observance of the grammar rules acquired at school (in the case of Uganda) and the application of such grammar rules to quotidian discourse in English. Research has shown that total immersion is crucial in second language proficiency (Genesse, 1985).

If indeed immersion is a contributing factor (cf. Genesse, 1985), it is therefore quite clear why the business community also displayed more deviations than the students. This is because the business community rarely uses English, despite the fact that they gained proficiency in it while at school or university. The business community primarily deals with the local community and will typically use the indigenous language, i.e. Acholi, while making business transactions. The acrolectal level of proficiency is attained after 13 years of learning English (Greenbaum \& Nelson, 1996), i.e. the equivalent of Advanced Level education. Uganda has only $7.3 \%$ of its population who have attained Advanced Level or its equivalent (Uganda Bureau of Statistics, 2016, p. 26). Using the total population of Gulu City (where our respondents came from), i.e. 92,877.24 (Uganda Bureau of Statistics, 2016), we are able to estimate that only around 6,780 people speak English acrolectally (i.e. 92,877.24 x 7.3/100) in the City. Even if we were to extend the number of speakers to those who have just completed Form 4 of secondary education (i.e. 11 years of English education), with statistics indicating $15.4 \%$ of Ugandans having attained this level (Uganda Bureau of Statistics, 2016, p. 26), the number would only increase to around 13,000 people. Thus, even if these people were to speak English only with the business community, still they would only cover approximately $13 \%$ of the population, which is quite insignificant in terms of immersion. Although some sporadic use of English may be observed among the business community (e.g. when they go to the bank where the teller may not speak Acholi), this is very limited. Hence, it is clear that the business community is also less exposed to daily use of English (albeit not at the same level as teachers of English), a situation that might have impacted on their exonormative proficiency, as observed in the elicitation test.

\section{Conclusion}

The findings in this study show that L1 Acholi speakers of English as a L2 display a number of deviations. The study therefore lends support to previous studies, where, e.g. Kachru (1985) argues that L2 speakers will usually speak in a distinct manner from L1 speakers due to the fact that their L2 English is a result of contact phenomena, where the L1 plays a role, in addition to the second language acquisition process of leveling. While this study shows the role of Acholi in how its speakers handle the English order of adjectives and placement of adverbs, it does not rule out the extrapolation of the observed behavior to 
other Ugandans if their L1s behave in the same way as Acholi as regards the two grammatical aspects under consideration. A comparative study is therefore envisioned. Crucially, the current study augments discourse on the structural nativization of English in Uganda and has brought to the limelight further evidence of grammatical divergences that occur in Ugandan English (cf. Fisher, 2000; Isingoma, 2016; Ssempuuma, 2019, among others). It thus supports the characterization of English in Uganda as having reached at least Phase 3 (i.e. the nativization phase) in its trajectorial development (cf. Isingoma \& Meierkord, 2016) in keeping with Schneider's model (Schneider, 2007) on the development of postcolonial Englishes; that is, the emergence and manifestation of visible differences (with the parent variety, i.e. British English) in syntax as well as in other areas of linguistic analysis (i.e. morphology, phonology, lexis, as well as the interface of these with semantics and pragmatics).

The current study also evinces the fact that both Outer Circle varieties and Expanding Circle varieties (cf. Kachru, 1985) share deviations as regards word order in English. Despite the fact that there is more English usage in Outer Circle countries, such as Uganda, than in Expanding Circles, such as China, substrate influence from L1 still plays a substantial role in either case (see, e.g. Wulff \& Gries, 2015 for the case of China). In fact, even within Outer Circle countries, there are different usage patterns, with some speaker groups using English more than other speaker groups (as shown in this study). This instantiates Michieka's observation (Michieka, 2009) about the manifestation of Expanding Circle linguistic behavior in Outer Circle countries, thereby blurring, to some extent, the borderline between the two categories in the Kachruvian model.

From the findings of this study, it seems right to posit that exonormative rules are more observed in school settings than elsewhere in Uganda. This seems to cause variability among users of English whether they share other social variables or not. Thus, despite the respondents being homogeneous in terms of ethnicity, thereby sharing the same L1, their observance of the rules of L1 English grammar varies according to their occupational status, with students being more disposed to follow the rules of grammar. This is an interesting dimension in the study, as English teachers should have been at the forefront in this respect, given that it is they who impart the rules to the students. But given that their level of practice is low compared to students (who are compelled to speak English all the time at school), this may be responsible for the disparity observed above, as the teachers are only compelled to speak English while in class teaching or when interacting with students on the compound or in the staffroom (but not, e.g. amongst themselves while at school). 


\section{References:}

Anthony, L. (2014). AntConc (Version 3.4.4w) [Computer Software]. Tokyo: Waseda University. Retrieved on 20th June 2021 from http://www.laurenceanthony.net.

BBC - Learning English. Retrieved on 20th June 2021 from https://www.bbc. co.uk/worldservice/learningenglish/flatmates/episode75/languagepoint.shtml.

Cambridge Dictionary. English Grammar Today. Retrieved on 25th June 2021 from https://dictionary.cambridge.org/grammar/british-grammar/already.

Cambridge Dictionary. English Grammar Today. Available at: https://dictionary. cambridge.org/grammar/british-grammar/already. Accessed 25th June 2021.

Carter, R. \& McCarthy, M. (2006). Cambridge Grammar of English . Cambridge: Cambridge University Press.

Cinque, G. (1999). Adverbs and Functional Heads: A Cross-linguistic Perspective. Oxford: Oxford University Press.

Chomsky, N. (1965). Aspects of the Theory of Syntax. Cambridge, MA: MIT Press.

Chomsky, N. (1986). Knowledge of Language: Its Nature, Origin and Use. New York, NY: Praeger.

Eberhard, M. D., Simons, F. G., \& Fennig C. D. (Eds.) (2021). Ethnologue: Languages of the World, 24th ed. Dallas, TX: SIL International.

Fisher, E. C. A. (2000). Assessing the state of Ugandan English. English Today, $16,57-61$.

Genesse, F. (1985). Second language learning through immersion: A review of U.S. programs. Review in Education Research, 55(4), 541-561.

Greenbaum, S., \& Nelson, G. (1996). The International Corpus of English (ICE) Project. World Englishes 15, 3-15.

Harakawa, M., Shibuya, M., \& Endo, M. (2019). Explicit instruction, input flood or study abroad: Which helps Japanese learners of English acquire adjective ordering? Language Teaching Research, 23(2), 158-178.

Hasselgård, H., Lysvåg, P. \& Johansson, S. (2012). English Grammar: Theory and Use. Oslo: Universitetsforlaget.

Haumann, D. (2007). Adverb Licensing and Clause Structure in English. Amsterdam: Benjamins.

Isingoma, B. (2016). Ditransitive constructions in Ugandan English. In C. Meierkord, B. Isingoma \& S. Namyalo (Eds.), Ugandan English: Its Sociolinguistics, Structure and Uses in a Globalising Post-protectorate (pp. 201-226). Amsterdam: Benjamins.

Isingoma, B., \& Meierkord, C. (2016). Ugandan English: Challenges to - and food for, current theories. In C. Meierkord, B. Isingoma \& S. Namyalo (Eds.), 
Ugandan English: Its Sociolinguistics, Structure and Uses in a Globalising Post-protectorate (pp. 1-15). Amsterdam: Benjamins.

Isingoma, B., \& Meierkord, C. (2019). Capturing the lexicon of Ugandan English: ICE-Uganda and its effective complements. In: A. U. Esimaje, U. Gut \& B. E. Antia (eds). Corpus Linguistics and African Englishes (pp. 294328). Amsterdam: Benjamins.

Kachru, B. (1985). Standards, codification and sociolinguistic realism: The English language in the outer circle. In R. Quirk \& H. G. Widdowson (Eds.), English in the world. Teaching and Learning the language and literatures (pp. 11-30). Cambridge: CUP.

Karpava, S. (2017). Acquisition of L2 English adverb placement by Russian and Greek Cypriot speakers. Proceedings of 8th Tutorial and Research Workshop on Experimental Linguistics, 19-22 June (pp. 49-52), Heraklion, Crete, Greece.

Kitikanan, P., \& Dandmrongak, S. (2018). English adjective order ability by L2 Thai learners. In Proceedings of the 3rd International Conference of Multidisciplinary Approaches on UN Sustainable Development Goals (UNSDGs), (pp 116-121). Research and Development Institute Nakhon Pathom Rajabhat University.

Kitching, L.A. (1932). An outline grammar of the Acholi language. London: The Sheldon Press.

Kroeger, R. P. (2004). Analyzing syntax: A lexical-functional approach. Cambridge: Cambridge University Press.

McMahon, S. (2008). Prenominal adjective usage: Multiple pre-nominal adjective usages by Asian L2 learners of English. Senior Honors thesis, Liberty University.

Meierkord, C. \& Isingoma, B. (2021, accepted). Between first language influence, exonormative orientation and migration - future time expressions in post-protectorate Ugandan English. English World-Wide.

Michieka, M. M. (2009). Expanding circles within outer circles: The rural Kisii in Kenya. World Englishes, 28(3), 352-364.

Schmied, J. (2004). East African English (Kenya, Uganda, Tanzania): morphology and syntax. In Kortmann, B. \&. Schneider, W. E. (Eds). A handbook of varieties of English, Volume II: Morphology and Syntax (pp. 929-947). Berlin: Mouton de Gruyter.

Schneider, W. E. (2007). Postcolonial English: Varieties around the world. Cambridge: CUP.

Sprouse, R. A. (2006). Full transfer and relexification: Second language acquisition and Creole genesis. Amsterdam: Benjamins. 
Ssempuuma, J. (2019). Morphological and Syntactic Feature Analysis of Ugandan English: Influence from Luganda, Runyankole-Rukiga and AcholiLango. Bern: Peter Lang.

Ssempuuma, J., Isingoma, B., \& Meierkord, C. (2016). The use of the progressive in Ugandan English. In: C. Meierkord, B. Isingoma \& S. Namyalo (eds.), Ugandan English: Its Sociolinguistics, Structure and Uses in a Globalizing Post-protectorate (pp. 173-199). Amsterdam: John Benjamins.

Uganda Bureau of Statistics (2016). The National Population and Housing Census 2014 - Main Report, Kampala Uganda.

Wulff, S. \& Gries, Th. S. (2015). Prenominal adjective order preferences in Chinese and German L2 English: A multifactorial corpus study. Linguistic Approaches to Bilingualism, 5(1), 122-150.

Zhang, Z. (2010). The syntactic positions of adverbs and the second language acquisition. Sino-US English Teaching, 7.9 (81), 48-54. 


\section{Appendix 1}

Table 2.

Multiple comparisons of mean scores for the order of adjectives among speaker groups

\begin{tabular}{|c|c|c|c|c|c|c|}
\hline \multirow{2}{*}{$\begin{array}{l}\text { (I) Adjective } \\
\text { scores }\end{array}$} & \multirow{2}{*}{ (J) Adjective scores } & \multirow{2}{*}{$\begin{array}{l}\text { Mean Dif- } \\
\text { ference } \\
\text { (I-J) }\end{array}$} & \multirow{2}{*}{$\begin{array}{l}\text { Std. } \\
\text { Error }\end{array}$} & \multirow{2}{*}{ Sig. } & \multicolumn{2}{|c|}{$\begin{array}{c}\text { 95\% Confi- } \\
\text { dence Interval }\end{array}$} \\
\hline & & & & & $\begin{array}{l}\text { Lower } \\
\text { Bound }\end{array}$ & $\begin{array}{l}\text { Upper } \\
\text { Bound }\end{array}$ \\
\hline \multirow{2}{*}{$\begin{array}{l}\text { Business Commu- } \\
\text { nity }\end{array}$} & \begin{tabular}{|l} 
Students \\
\end{tabular} & $-.30000^{*}$ & .00000 & .000 & -.3000 & -.3000 \\
\hline & English teachers & $.10000^{*}$ & .00000 & .000 & .1000 & .1000 \\
\hline \multirow[t]{2}{*}{\begin{tabular}{|l|} 
Students \\
\end{tabular}} & $\begin{array}{l}\text { Business Commu- } \\
\text { nity }\end{array}$ & $.30000^{*}$ & .00000 & .000 & .3000 & .3000 \\
\hline & English teachers & $.40000^{*}$ & .00000 & .000 & .4000 & .4000 \\
\hline \multirow[t]{2}{*}{ English teachers } & $\begin{array}{l}\text { Business Commu- } \\
\text { nity }\end{array}$ & $-.10000^{*}$ & .00000 & .000 & -.1000 & -.1000 \\
\hline & Students & $-.40000^{*}$ & .00000 & .000 & -.4000 & -.4000 \\
\hline
\end{tabular}

Table 3.

Multiple comparisons of the mean scores for the order of adverbs among speaker groups

\begin{tabular}{|c|c|c|c|c|c|c|}
\hline \multirow{2}{*}{ (I) Adverb scores } & \multirow{2}{*}{ (J) Adverb scores } & \multirow{2}{*}{$\begin{array}{c}\text { Mean } \\
\text { Differ- } \\
\text { ence (I-J) }\end{array}$} & \multirow{2}{*}{$\begin{array}{l}\text { Std. } \\
\text { Error }\end{array}$} & \multirow{2}{*}{ Sig. } & \multicolumn{2}{|c|}{$\begin{array}{l}\text { 95\% Confi- } \\
\text { dence Interval }\end{array}$} \\
\hline & & & & & $\begin{array}{l}\text { Lower } \\
\text { Bound }\end{array}$ & $\begin{array}{l}\text { Upper } \\
\text { Bound }\end{array}$ \\
\hline \multirow{2}{*}{$\begin{array}{l}\text { Business Commu- } \\
\text { nity }\end{array}$} & Students & $-.70000^{*}$ & .00000 & .000 & -.7000 & -.7000 \\
\hline & English teachers & $-.80000^{*}$ & .00000 & .000 & -.8000 & -.8000 \\
\hline \multirow[t]{2}{*}{ Students } & $\begin{array}{l}\text { Business Commu- } \\
\text { nity }\end{array}$ & $.70000^{*}$ & .00000 & .000 & .7000 & .7000 \\
\hline & English teachers & $-.10000^{*}$ & .00000 & .000 & -.1000 & -.1000 \\
\hline \multirow[t]{2}{*}{ English teachers } & $\begin{array}{l}\text { Business Commu- } \\
\text { nity }\end{array}$ & $.80000^{*}$ & .00000 & .000 & .8000 & .8000 \\
\hline & Students & $.10000^{*}$ & .00000 & .000 & .1000 & .1000 \\
\hline
\end{tabular}




\section{Appendix II: Elicitation Test}

\section{(1) Adjectives}

For each of the following sentences, indicate whether they are grammatically correct or incorrect based on your judgment.

(1) a The man who passed is a short lazy Ugandan man.

b. The man who passed is a Ugandan short lazy man.

(2) a. The ball I bought was a dirty old green ball.

b. The ball I bought was a green old dirty ball.

(3) a. My mother has a beautiful wide pink door.

b. My mother has a pink wide beautiful door.

c. My mother has a wide pink beautiful door.

\section{(2) Adverbs}

For each of the following sentences, indicate whether they are grammatically correct or incorrect based on your judgment.

(1) a. Obviously, he had spoken loudly.

b. Loudly, he had spoken obviously.

(2) a. He luckily has wisely refused the offer.

b. He wisely has luckily refused the offer.

(3) a. They have already gone home.

b. They already have gone home.

(4) a. The student unfortunately probably asked to stay behind.

b. The student probably unfortunately asked to stay behind.

(5) a. The man quickly removed his phone from the table.

b. The man removed his phone quickly from the table.

c. The man removed his phone from the table quickly.

(6) a. Possibly, he has gone.

b. He has gone, possibly.

(7) a. Clearly, Dorica probably will quickly learn French perfectly.

b. Probably, Dorica clearly will quickly learn French perfectly. 